\title{
Ketidaksetaraan Gender dalam Novel Perempuan di Titik Nol Karya Nawal El-Saadawi
}

\author{
Suparman \\ Fakultas Bahasa dan Sastra Universitas Cokroaminoto \\ Jalan Latammacelling No. 19, Kota Palopo, Sulawesi Selatan \\ Ponsel: 085261455244 \\ Posel:prahauh@yahoo.co.id
}

\begin{abstract}
Abstrak
Penelitian ini bertujuan mendeskripsikan ketidakadilan gender dalam bidang sosial, politik dan ekonomi serta bentuk perlawanan tokoh utama dalam Perempuan di Titik Nol, novel Karya Nawal el-Saadawi. Penelitian ini merupakan penelitian kepustakaan bersifat deskriptif kualitatif. Sumber data adalah novel Perempuan di Titik Nol Karya Nawal el-Saadawi yang diterbitkan oleh Yayasan Obor Indonesia 2006. Data dalam penelitian ini berupa kutipan kata, frasa, klausa, kalimat dan paragraf dari novel. Dari hasil penelitian ini, ditemukan dua hal yakni, 1) ketidakadilan gender dalam bidang sosial pada novel Perempuan di Titik Nol berupa tindakan kekerasan, penghinaan dan pelecehan terhadap tokoh utama serta cacian dari kaum laki-laki. Ketidakadilan gender dalam bidang politik berupa batasan untuk memperoleh pendidikan dan dibatasinya ruang bagi kaum perempuan untuk terlibat dalam ranha politik. Ketidakadilan gender dalam bidang ekonomi pada novel Perempuan di Titik Nol berupa beban kerja yang dialami oleh tokoh Firdaus yang sangat padat sehingga dia harus bekerja keras untuk bertahan hidup. Bentuk perlawanan tokoh utama dalam Novel Perempuan di Titik Nol berupa perlawanan tokoh utama terhadap proses stereotip, subordinasi marginal dan kekerasan terhadap perempuan.
\end{abstract}

Kata kunci: novel, ketidakadilan gender, feminisme

\section{Gender Inequality in The Novel Perempuan di Titik Nol of Nawal El-Saadawi}

\begin{abstract}
This research aims to reveal and describe gender inequity in Perempuan di Titik Nol novel by Nawal el-Saadawi in social, political, and economic sectors and the main character's resistance. This is a library research using descriptive qualitative method. Data source of this study is Perempuan di Titik Nol novel by Nawal el-Saadawi, published by Yayasan Obor Indonesia in 2006. Data of the research are quoted words, phrases, clauses, sentences, and paragraphs from the novel Perempuan di Titik Nol by Nawal el-Saadawi. The results of this study discovered 3 issues, i.e. 1) gender inequities in social sector in the novel Perempuan di Titik Nol are the main character experienced many acts of violence, humiliation, and harassment against her as well as insult from men, 2) gender inequities in politic sphere are a limitation to obtain education and space for women to be involved in politic field, and 3) gender inequities in economic sector are the workload experienced by Firdaus is extremely heavy so he must work hard to be able to survive. The main character's resistance in the novel Perempuan di Titik Nol is the resistance to the stereotyping, marginal subordination, or violence against women.
\end{abstract}

Keywords: novel, gender inequity, feminism

\section{PENDAHULUAN}

Karya sastra merupakan kehidupan sosial masyarakat di sekitar pengarang. Karya sastra adalah kenyatan sosial yang benarbenar nyata terjadi dalam masyarakat. Pengarang memberikan gambaran nyata kehidupan masyarakat melalui cerita yang didasari pengalaman sebagai anggota masyarakat. Faktor pembangun dalam karya sastra tidak hanya unsur intrinsik, namun dapat berupa unsur ekstrinsik yang membangun keutuhan suatu karya sastra (Rondiyah, dkk., 2017: 223). Salah satu bentuk karya sastra adalah novel.

Nurgiyantoro memaparkan bahwa novel/roman umumnya mengungkapkan persoalan-persoalan sosial masyarakat pada suatu masa tertentu. Dalam novel, terdapat 
keleluasaan menggunakan bahasa atau katakata untuk melukiskan, menguraikan, dan menafsirkan sesuatu lewat adegan, situasi, dan tokoh yang bermacam-macam latar belakangnya.

Goldmann (dalam Suparman, 2014) mendefinisikan "novel sebagai cerita mengenai pencarian yang terdegradasikan oleh nilai-nilai otentik dalam dunia yang juga terdegradasi. Pencarian itu dilakukan oleh seorang hero yang problematik", lebih lanjut dikatakannya bahwa novel merupakan suatu genre sastra yang bercirikan keterpecahan yang tidak terdamaikan dalam hubungan antara sang hero dengan dunia. Keterpecahan itulah yang menyebabkan dunia dan hero sama-sama terdegradasi dalam hubungannya dengan nilai-nilai otentik yang berupa totalitas. Keterpecahan itulah yang menyebabkan atau membuat sang hero menjadi problematik.

Gender merupakan suatu sifat yang melekat pada kaum laki-laki dan perempuan yang dikonstruksi secara sosial maupun kultural (Fakih, 2013). Konsep gender kemudian menghasilkan dua kategori yang dikotomis, yaitu feminitas yang melekat pada kaum perempuan dan maskulinitas yang identik pada kaum laki-laki (Ashaf, 2009).

Berbagai permasalahan yang dihadapi perempuan masa kini masih menunjukkan sebagian gambaran permasalahan masa lalu yang belum terselesaikan. Seperti telah dikemukakan di berbagai penelitian, masalah kini semakin kompleks terkait permasalahan perempuan yang hidup di zaman modern, berbagai permasalahan yang muncul merupakan senyawa dari masalah lokal/internal dan global/eksternal yang dihadapi oleh kaum perempuan, baik dalam hal politik, sosial, ekonomi dan budaya.

Banyak kaum perempuan mengalami tekanan di bidang sosial ekonomi. Munculnya berbagai masalah dalam kehidupan perempuan muncul dari berbagai kondisi, hal yang paling banyak dihadapi oleh perempuan adalah kemiskinan dan tingkat pendidikan yang rendah. Saat ini, banyak perempuan di memiliki peran ganda, di satu sisi sebagai ibu rumah tangga dan di sisi lainnya sebagai wanita karier yang ternyata belum diimbangi oleh perubahan ideologi, infrastrukrur dan tata nilai-nilai religius yang memadai.

Peran ganda juga ini terjadi pada diri seorang Firdaus yang menjadi tokoh utama dalam Novel Perempuan di Titik Nol. Arus peran ganda ini merupakan konsekuensi logis bagi seorang perempuan dari hadirnya industrialisasi dan urbanisasi serta kondisi ekonomi negara yang ada dalam krisis berkepanjangan yang dialami beberapa negara berkembang di dunia. Dalam hal transformasi menuju era masyarakat industri dan kondisi krisis yang berkepanjangan dalam hal bidang politikk, ekonomi dan sosial tersebut, wanita dipaksa untuk menjadi pekerja dalam keluarga sebagai konsekuensi dari beban ganda. Hal yang paling kompleks dihadapi perempuan saat ini adalah rendahnya tingkat pendidikan secara umum yang dimanifestasikan ke dalam keterampilan buruh, sehingga para buruh perempuan masuk dalam kelompok yang rentan berada dalam lingkungan kerja yang kotor, berbahaya, serta kesukaran.

Novel Perempuan di Titik Nol lahir dari pencarian penulisnya atas kondisi kejiwaan seorang perempuan bernama Firdaus yang dipenjara dengan tuduhan pembunuhan terhadap seorang lelaki. Novel ini menggambarkan sosok para lelaki yang bersikap kasar pada perempuan. Firdaus memiliki seorang paman. Paman yang dicintainya itu suka menyentuh tubuhnya sejak kecil dan dianggapnya paling mengerti dirinya. Firdaus sebenarnya tidak suka, terutama bahwa suami tuanya merupakan lelaki yang sangat kasar, suka memukulinya, jorok dan pelit.

Pembagian kerja berdasarkan gender yang menempatkan perempuan dalam ranah domestik, sementara laki-laki dalam ranah publik jelas menimbulkan kesenjangan kelas karena sebagai pekerja di ranah publik, lakilaki menguasai wilayah produksi. Secara ekonomi, laki-lakilah yang menghasilkan materi, sementara perempuan, walaupun 
mengeluarkan tenaga dan menggunakan hampir seluruh waktunya untuk bekerja di rumah dia tidak mendapatkan penghasilan. Bahkan, secara ekomoni perempuan sebagai ibu rumah tangga tergantung kepada lakilaki. Perempuan tidak menguasai materi (kepemilikan benda maupun uang) karena sebagai ibu rumah tangga, dia tidak mendapatkan penghasilan. Oleh karena itu, dia harus tunduk dan patuh kepada suaminya. Hal inilah yang memungkinkan perempuan tertindas.

Banyak gagasan tradisional mengenai gambaran wanita dan peranan mereka diceritakan sangat rendah. Ada anggapan bahwa wanita kurang memiliki kemampuan, bodoh, dan acuh tak acuh terhadap lingkungan mereka. Gambaran tradisional, antara lain, mengatakan bahwa wanita sudah sewajarnya hidup terbatas dalam lingkungan rumah tangga, dan mengurus anak. Tugas wanita seperti itu oleh sebagian kaum wanita dapat diterima. Menurut mereka, hal itu merupakan tugas yang diberikan oleh alam kepadanya. Hal yang dirasakan sangat sulit diterima oleh sebagian besar wanita adalah adanya penindasan ideologi gender atau kekuasaan pria atas wanita dalam segala bidang. Golongan wanita yang tidak rela menerima perlakuan ini disebut feminisme. Oleh karena itu, lahirlah suatu kesadaran wanita untuk menuntut persamaan hak dengan pria. Hal ini dapat dilihat pada kehidupan masyarakat Indonesia dewasa ini yang tidak membedakan hak dan kewajiban seorang wanita dan laki-laki dalam bidang politik, ekonomi, dan sosial (Sugihastuti, 2002, hlm. 139).

Eko feminisme adalah paham yang ingin mengembalikan kesadaran manusia akan pentingnya dihidupkan kualitas feminisme di dalam masyarakat, dan menerima perbedaan antar laki-laki dan perempuan. Pemerosotan martabat perempuan oleh laki-laki sebagai bagian dari segregasi dan subordinasi. Kaum feminis sepakat bahwa penempatan perempuan sebagai korban secara sosial, politik, dan ekonomi merupakan akibat dari struktur dalam masyarakat secara luas di mana perempuan dikontrol oleh laki-laki. Deskripsi mengenai perempuan yang menjadi korban terjadi pada seluruh kritik feminis. Namun, secara umum kritik feminisme mendeskripsikan perlakuan itu secara kausal dan struktural.

Penelitian novel dengan kajian feminis pernah dilakukan oleh Lismaena $M$ Alirus (2008) dengan judul "Aspek Feminisme dalam Novel Serpihan Mutiara Retak Karya Nina Pane". Hal yang menjadi perhatian utama dalam penelitian ini adalah aspek feminisme secara umum dan tidak menspesifikkan pada aspek feminisme radikal yang diteliti dalam tulisan ini. Penelitian yang dilakukan oleh Lismaena tidak menyinggung masalah ketidakadilan gender dan bentuk perlawanan kaum wanita. Penelitian ini berfokus pada aspek ketidakadilan gender yang secara garis besar tertuang dalam kajian feminisme radikal.

Berdasarkan latar belakang yang telah dipaparkan tersebut, masalah penelitian ini dijabarkan ke dalam dua masalah, yaitu: 1) bagaimanakah ketidakadilan gender yang disebabkan oleh perbedaan biologis dalam aspek sosial, politik dan ekonomi pada novel Perempuan di Titik Nol karyaNawal-el-Saadawi? dan 2) bagaimanakah perlawanan tokoh utama dalam bidang sosial, politik dan ekonomi pada novel Perempuan di Titik Nol karya Nawal el-Saadawi?

\section{TEORI}

Feminisme radikal lahir dari aktivitas dan analisis politik mengenai hakhak dan gerakan-gerakan perubahan sosial pada tahun 1950-an dan 1960-an; serta gerakan-gerakan wanita yang semarak pada tahun 1960-an dan 1970-an. Namun demikian, mazhab ini dapat dilacak pada para pendukungnya yang lebih awal. Lewat karyanya, Vindication of the rights of women, Mary Wollstonecraft pada tahun 1797 menganjurkan kemandirian wanita dalam bidang ekonomi. Maria Stewart, salah satu feminis kulit hitam pertama pada tahun 1830 -an mengusulkan penguatan relasi- 
relasi di antara warna kulit hitam. Elizabeth Cuddy Stanton pada tahun 1880-an menentang hak-hak seksual laki-laki terhadap wanita dan menyerang justifikasi keagamaan yang menindas wanita (Suharto, 2002: 11).

Menurut Humm (2007: 157-158), feminisme menggabungkan doktrin persamaan hak bagi perempuan yang menjadi gerakan yang terorganisasi untuk mencapai hak asasi perempuan, dengan sebuah ideologi transformasi sosial yang bertujuan untuk menciptakan dunia bagi perempuan. Selanjutnya Humm menyatakan bahwa feminisme merupakan ideologi pembebasan perempuan dengan keyakinan bahwa perempuan mengalami ketidakadilan karena jenis kelaminnya. Feminisme menawarkan berbagai analisis mengenai penyebab, pelaku dari penindasan perempuan (Humm, 2007: 157-158). Dinyatakan oleh Ruthven (1985:6) bahwa pemikiran dan gerakan feminisme lahir untuk mengakhiri dominasi laki-laki terhadap perempuan. Melalui proyek (pemikiran dan gerakan) feminisme, struktur budaya, seni, gereja, hukum, keluarga inti yang berdasarkan pada kekuasaan ayah dan negara harus dihancurkan, juga semua citra, institusi, adat istiadat, dan kebiasaan yang menjadikan perempuan sebagai korban yang tidak dihargai dan tidak tampak.

Agger (1998) menyatakan bahwa prestasi besar dari teori feminis adalah bahwa gerakan itu bukan hanya tentang pemahaman, namun juga tentang tindakan. Feminis itu sendiri, membentuk kesadaran yang dibangun pengalaman perempuan yang khas tentang kebenaran, pengetahuan dan kekuasaan. Seperti halnya yang terjadi dalam masyarakat, perkembangan berikutnya, feminisme juga mendapat respon yang lain dari isme-isme Barat, seperti kapitalisme, sosialisme, modernisme, industrialisme dan bahkan postmodernisme. Feminisme tidak lebih hanya diterima sebagai entitas yang secara substansial tercela dan tidak perlu diberi ruang (Fakih, 2000: 235). Namun, hal ini tidak menyurutkan dan memusnahkan munculnya gerakan feminis sendiri. Kesadaran akan ketertindasan muncul di belahan dunia manapun. Diakui atau tidak, feminisme menjadi suatu fenomena yang mendesak kemapanan patriakal yang cenderung mendiskriditkan martabat kemanusiaan perempuan. Kesadaran tersebut telah menciptakan paradigma baru yang lebih harmonis untuk laki-laki dan perempuan, serta merumuskan identitas gender yang tidak terlalu tajam terpolarisasi dalam sudut-sudut yang superioritas dan inferior.

Teori feminisme selama ini digunakan untuk menyelesaikan persoalan-persoalan penelitian yang berfokus pada peran dan posisi perempuan dalam semua aspek kehidupan. Teori ini juga digunakan sebagai pisau bedah terhadap ketimpangan yang terjadi antara perempuan dan laki-laki. Setelah berabad-abad diabaikan, disingkirkan dan diremehkan oleh disiplin ilmu patriarki, perempuan berusaha menjadi bahan objek penyelidikan. Teori-teori tradisional sering dimodifikasi oleh kaum feminis untuk menerangkan penindasan terhadap perempuan. Dengan memusatkan pada pencantuman persamaan perempuan ke dalam kerangka teoritik masa lalu, kesamaan-kesamaan perempuan dan lakilaki ditekankan (Gross, 1986: 194).

Philips mengatakan, pergeseran saat ini dari penekanan pada identitas ke perbedaan, telah memindahkan feminisme ke luar persoalan eksklusi/inklusi perempuan ke isu kurang spesifik-gender yang diasosiasikan dengan homogenitas/heterogenitas,kesamaan/keane karagaman dan universalitas/ perbedaan. Dengan hal tersebut sebagai latar belakang, perbedaan identitas mulai dilihat secara positif, bukan sebagai penghalang bagi mobilitas politik. Namun, teori feminis tak terbatas pada menyediakan alat untuk memikirkan kembali "isu perempuan" atau peran perempuan di dalam politik praktis, walaupun tugas tersebut juga penting (Gaus\&Kukathas, 2012:649).

Lebih dari hal tersebut, teori politik feminis telah mentransformasi cara pikir 
tentang isu-isu utama dalam teori politik, termasuk negara, relasi-relasi antara ranah publik dan ranah pribadi, kewarganegaraan serta aspek inti lain dalam teori demokrasi. Terutama, teori feminisme telah memperluas gagasan kekuasaan dan gagasan yang politis. Teori feminis telah menjalankan gerak rangkap. Pertama, teori politik feminis memperluas gagasan tentang yang politis sampai pada situs-situs kekuasaan di luar arena politik formal dan lembaga-lembaga kunci di ranah publik seperti negara, hingga menjangkau kehidupan keluarga dan seksualitas sebagai situs ketidaksetaraan gender dan situs konstruksi identitas gender. Pada tingkat politis praktis, politisasi seksualitas juga penting sebagai bagian utama dari klaimklaim politis feminis, seperti isu kontrasepsi, kekerasan seksual, pornografi dan pelecehan seksual.

Gerak yang kedua di dalam teori politik feminisme dewasa ini berupa perbaruan minat pada peran negara dalam mengatur relasi gender. Teorisasi feminis untuk negara dalam tahun-tahun ini cenderung meninggalkan generalisasi teoriteori negara dan lebih meningkatkan generalisasi teori-teori negara dan lebih meningkatkan fokus pada analisis praktikpraktik diskursif yang mengkonstruksi gender oleh politik, juga proses terbentuknya politik oleh gender (Gaus \& Kukathas, 2013:651).

Persoalan-persoalan

tertentu menempatkan feminisme radikal berbeda dengan persfektif feminisme lainnya, terutama pandangan sosialis akan sentralitas kelas dan pandangan perempuan kulit hitam akan sentralitas ras. Juliet Mitchell mengkritik Fireston secara khusus dan feminisme radikal pada umumnya karena tidak berbicara mengenai penindasan perempuan dalam cara tertentu secara historis.

Salah satu dari feminis radikal yang pertama bersikeras menyatakan bahwa akar opresi terhadap perempuan sudah terkubur dalam di dalam sistem seks/gender di dalam patriarki adalah Kate Millett. Millet berpendapat dalam bukunya Sexual Politics (1970), bahwa seks adalah politis, terutama karena hubungan laki-laki dan perempuan merupakan paradigma dari semua hubungan kekuasaan. Ideologi patriakal, menurut Millett, membesar-besarkan perbedaan biologis antara laki-laki dan perempuan, ketika laki-laki selalu mempunyai peran yang dominan dari pada perempuan (Ariyana, 2007, hlm. 1).

Berdasarkan pandangan yang menyatakan bahwa inti gerakan feminis radikal adalah melakukan perlawanan terhadap penindasan perempuan yang dilakukan oleh laki-laki. Penindasan terjadi karena adanya pemisahan antara ranah privat dan ranah publik. Pernyataan terebut menunjukan bahwa kaum feminis menolak adanya pemisahan antara ranah privat dan sosial. Menurut mereka, kedua ranah terebut memiliki hubungan yang saling memengaruhi. Ranah privat berpengaruh terhadap ranah publik, begitu juga sebaliknya. Selain itu, feminis radikal memiliki asumi bahwa dengan adanya pemisahan antara ranah privat dan publik, ranah privat memiliki posisi yang lebih rendah jika dibandingkan dengan ranah sosial. Hal tersebutlah yang memicu munculnya slogan gerakan feminis radikal, yaitu the personal is political (yang pribadi adalah politis). Ini berarti bahwa berbagai penindasan yang terjadi di ruang pribadi merupakan penindasan yang berlangsung di ranah publik. Feminis radikal memberikan prioritas pada upaya untuk menyadarkan perempuan bahwa perempuan memiliki hak penuh atas tubuh mereka sendiri sehingga perempuan memiliki kebebasan penuh untuk memutuskan segala sesuatu yang berkaitan dengan tubuh mereka, termasuk dalam hal keperawanan Arivia (dalam Kurnianto, 2017: 285)

\section{METODE}

Jenis penelitian yang digunakan dalam penelitian ini adalah penelitian deskriptif kualitatif, yaitu peneliti mendeskpripsikan data secara objektif atau sesuatu yang sesuai dengan keadaannya 
mengenai ketidakadilan gender dalam novel Perempuan di Titik Nol karya Nawal elSaadawi.

Data dalam penelitian ini adalah kutipan dari isi cerita dalam novel Perempuan di Titik Nol karya Nawal elSaadawi yang mengandung ketidakadilan gender, yang terbagi ke dalam tiga data, yakni: data ketidakadilan gender dalam bidang sosial, data ketidakadilan gender dalam bidang politik, dan data ketidakadilan gender dalam bidang ekonomi. Sumber data penelitian ini adalah novel Perempuan di Titik Nol karya Nawal el-Saadawi yang ditebitkan oleh Yayasan Obor Indonesia 2006 dengan jumlah halaman sebanyak 115 .

\section{HASIL DAN PEMBAHASAN Ketidakadilan Gender yang Disebabkan oleh Perbedaan Biologis}

\section{Ketidakadilan Gender Disebabkan oleh Perbedaan Biologis dilihat dari Aspek Sosial}

Terkadang aturan dalam masyarakat membuat seorang perempuan termarginalkan oleh kaum laki-laki. Hal itu membuat kaum perempuan berada dalam kecaman kaum laki-laki tidak melepaskan diri dari kungkungan kaum superior. Hal ini yang biasa menimbulkan kekerasan terhadap kaum minoritas. Apabila kaum perempuan masih tetap bertahan dalam posisi sebagai kaum yang inferior, tempat bagi seorang perempuan hanya rumah. Namun, secara garis besar seorang perempuan mampu melepaskan diri dari kungkungan kaum superior ketika ia mampu bangkit dari keterpurukan dan melepaskan diri dari kekuasaan laki-laki.

Diri seorang perempuan terkadang menjadi kaku ketika mereka merasa dikuasai oleh kaum laki-laki sehingga seorang perempuan menjadi luluh oleh kaum lakilaki. Hal inilah yang dialami oleh Firdaus, ketika seorang paman telah melakukan sesuatu yang menjadikan diri Firdaus gemetar.
Data 1

........sampai pada suatu saat saya melihat tangan paman saya pelanpelan bergerak dari balik buku yang sedang ia baca menyentuh kaki saya. Saat berikutnya saya dapat merasakan tangan itu menjelajahi kaki saya sampai paha dengan gerakan yang gemetaran dan sangat berhati-hati (elSaadawi, 2006, hlm. 20).

Kutipan tersebut menunjukkan bahwa Firdaus telah mengalami pelecahan oleh keluarga dekat mereka. Hal ini menunjukkan bahwa kaum perempuan berada di bawah tekan seorang laki-laki.

Di sisi lain, pengarang menggambarkan sisi kehidupan Firdaus yang kelam bersama sanak keluargayang telah memeliharanya sejak orang tuanya telah meninggalkannya. Fenomena ini menggambarkan betapa kerasnya kehidupan yang dijalani oleh Firdaus bersama keluarga pamannya. Pada suatu hari sepulang dari sekolah, Firdaus mendapati pamannya marah kepada istrinya sehingga pamannya memutuskan membawa Firdaus keluar dari rumah itu dan memasukkanya ke asrama putri. Hal ini dapat dilihat pada kutipan berikut:

Data 2:

Pada suatu hari, ketika saya pulang dari sekolah, saya dapati Paman kelihatan sangat marah kepada saya. Istrinya pun kelihatan sama marahnya, dan dia terus saja memperlihatkan muka yang marah, sampai Paman memutuskan untuk membawa saya keluar dari rumah dengan baju dan buku-buku saya, dan memasukkan saya ke dalam asrama putri yang menjadi bagian dari sekolah saya itu (el-Saadawi, 2006, hlm. 34).

Kutipan tersebut menunjukkan
bahwa kehidupan Firdaus bersama
pamannya tidak bahagia dengan diusirnya
Firdaus dari rumah pamannya dan membawa
Firdaus ke sebuah asrama. Hal ini
membuktikan bahwa betapa tersiksanya


seorang Firdaus yang telah lama ditinggal orang tuanya dan hidup menumpang di rumah pamannya.

Wanita penghibur dianggap sampah dalam masyarakat dan banyak merisaukan masyarakat sekitarnya. Wanita penghibur menjadi barang dagangan bagi para laki-laki penggiat maksiat, terkadang para wanita mendapat penghinaan oleh kaum laki-laki ketika mereka tidak melayani dengan sebaik-baiknya. Terkadang kondisi sosial mereka memaksa berada di jalan malang itu, jalan yang penuh dengan risiko tetapi hal ini dijalani oleh Firdaus karena desakan hidup. Perhatikan kutipan berikut:

Data 3:

"pelacur, perempuan jalang. “ Kemudian dia menghina ibu saya dengan kata-kata yang tak sanggup saya ikuti. Kemudian, ketika saya berusaha mengucapkannya, saya tak sanggup. Tetapi setelah malam itu , kata-kata itu seringkali saya dengar dari Bayoumi, dan kawan-kawan Bayoumi (el-Saadawi 2006: 72).

Pada kutipan di atas, pengarang menggambarkan seorang Firdaus yang telah dihina oleh Bayoumi dan teman-temannya dengan kata-kata yang begitu kasar dan tak sanggup didengar oleh Firdaus. Namun, Firdaus tidak merasa terpuruk akan kata-kata yang telah dilontarkan untuknya dan ia berusaha bangkit menjadi wanita terhormat bagi kaum laki-laki.

\section{Ketidakadilan Gender disebabkan oleh Perbedaan Biologis dilihat dari Aspek Politik}

Secara garis besar, peran seorang wanita dalam dunia politik masih terlalu minim sehingga politisi perempuan masih tenggelam dalam kekuasaan para politisi kaum laki-laki. Kaum perempuan masih belum berani untuk maju menjadi politisi yang kritis terhadap aturan kuota perempuan di dunia politik. Bahkan di dunia pendidikan pun perempuan masih kaku terhadap kaum laki-laki, tetapi Firdaus tidak pernah gentar akan suasana itu. Dia tidak menjadikan suasana itu sebagai suatu penghalang dalam menempuh kehidupan. Hal ini dapat dilihat pada kutipan berikut:

Data 4:

Saya senang bersekolah. Sekolah itu penuh dengan anak-anak lelaki dan perempuan. Kami bermain-main di halaman, terengah-engah sesak nafas karena berlari-lari Dari ujung yang lain (el-Saadawi, 2006, hlm. 29).

Kutipan di atas menggambarkan suasana hati Firdaus yang begitu senang bersekolah dan menikmati masa kecilnya dengan bermain-main dengan teman-teman sekolahnya. Pengarang dalam novel ini menunjukkan bahwa Firdaus sangat senang dalam menuntut ilmu di bangku sekolah.

Pengarang menggambarkan sosok wanita pemberani untuk mengungkap ketidaktertarikannya terhadap politik karena penyimpangan yang terjadi di dunia politik yang selalu menindas kaum lemah. Dalam novel ini, pengarang menggambarkan citra seorang penguasa yang hanya berfoya-foya dan hanya menjadi penguasa yang tidak peduli terhadap rakyatnya, memperlakukan wanita sebagai penghibur mereka, menjadikan anggur sebagai teman malam mereka, menyiksa rakyat sebagai hiburan mereka. Hal ini dapat dilihat pada kutipan berikut:

Data 5:

Tetapi saya lebih menyukai bukubuku tentang penguasa. Saya membaca kisah-kisah tentang para penguasa yang memiliki pelayan wanita dan selir sebanyak tentaranya, dan saya membaca tentang seorang penguasa lainnya yang perhatiannya dalam hidup itu hanya tertumpah pada anggur, perempuan dan mencambuki budak-budak beliannya, penguasa yang ketiga tidak banyak perhatian terhadap wanita, tetapi senang berperang, membunuh, dan menyiksa orang (el-Saadawi 2006: 38).

Pada kutipan di atas, pengarang memperlihatkan kebiasaan Firdaus yang senang membaca buku termasuk buku-buku 
tentang penguasa. Buku itulah yang memberikan pelajaran baru bagi Firdaus tentang kejahatan-kejahatan yang dilakukan oleh para penguasa yang bersenang-senang di atas penderiataan rakyatnya dan para wanita yang melayaninya.

Firdaus mencoba masuk ke dunia politik tetapi sang perempuan telah membaca wajah politik yang telah membawa banyak kesengsaraan pada rakyat kecil. Hal ini tidak terkecuali di belahan bumi manapun politik akan menjadi musuh para kaum tertindas yang tidak mendapat perhatian oleh para politisi setelah menjadi penguasa. Pengarang menggambarkan sosok penguasa yang berdiri tegak dalam kerakusan dan keangkuhan. Dari sebuah buku, Firdaus dapat mengetahui kebusukan para kaum politisi. Hal ini dapar dilihat pada kutipan berikut:

Data 6:

Saya dapat pula mengetahui bahwa semua yang memerintah adalah lelaki. Persamaan di antara mereka adalah kerakusan dan kepribadian yang penuh distorsi, nafsu, tanpa batas mengumpul uang, seks dan kekuasaan tanpa batas. Mereka adalah lelaki yang menaburkan korupsi di bumi, yang merampas rakyat mereka, yang bermulut besar, berkesanggupan untuk membujuk, memilih kata-kata manis, dan menembakkan panah beracun(elSaadawi, 2006, hlm.39).

Kutipan di atas menggambarkan sosok Firdaus yang memiliki rasa keingintahuan tentang dunia politik, dari situlah Firdaus baru mengetahui bahwa kaum lelakilah yang memerintah dan menjadi penguasa hanya memikirkan uang dengan melakukan korupsi, memikirkan kepuasan nafsunya dengan seks.

\section{Ketidakadilan Gender disebabkan oleh Perbedaan Biologis dilihat dari Aspek Ekonomi}

Dalam kehidupan masyarakat, terkadang ditemui sebagian kaum laki-laki yang perannya sebagai seorang ayah memiliki pengetahuan minim. Sebagian besar dari mereka berasal dari kalangan bawah yang memiliki perekonomian rendah sehingga dalam mencari nafkah untuk anggota keluarganya terkadang dilakukan dengan cara yang kurang wajar seperti mencuri, berlaku curang demi mendapatkan hasil yang memuaskan baginya tanpa memikirkan akibat yang akan dialaminya. Dapat dilihat pada kutipan berikut:

Data 7:

"Di samping itu, dari mana kita mencari uang untuk biaya hidup, dan buku serta bajunya? Kau tahu betapa tingginya biaya hidup sekarang ini. Harga-harga seperti bertambah gila, dan gaji pegawai pemerintah hanya naik sedikit sekali." (el-Saadawi, 2006, hlm. 52).

Dalam novel ini, digambarkan sosok Firdaus yang telah mulai hidup di tengahtengah para wanita malam. Novel ini menjadi cerminan bahwa demi untuk mempertahankan hidup tubuh seorang perempuan menjadi harga yang mahal ketika mereka menjadi penggiat seks demi bertahan hidup. Hal ini menjadi gambaran kehidupan di zaman sekarang yang telah menjadikan perempuan menjadi barang dagangan. Pengarang mencoba mengangkat realita yang tecermin dari masyarakat dunia di era modern, tidak terkecuali di Indonesia..

Sisi lain dari cerita hidup yang ditonjolkan pengarang terhadap kehidupan tokoh Firdaus adalah dia menjadi wanita penghibur yang selalu dicari oleh para pelangganya sedangkan pelanggan Firdaus bukan hanya orang-orang dari kalangan ekonomi menengah tetapi banyak dari kalangan politisi maupun aparat penegak hukum yang menjadi penjajal tubuh Firdaus. Hal ini dapat dilihat pada kutipan berikut: Data 8:

Ia berkata, "Saya akan membayar kau. Jangan mengira saya mau memakaimu dengan percuma. Saya bukannya seperti petugas polisi lainnya. Berapa kau minta? (el-Saadawi, 2006, hlm. 89).

Pada kutipan di atas, dapat kita lihat betapa kejam hidup yang dijalani oleh Firdaus sebagai wanita yang miskin. Gambaran ini menjadi bukti betapa kerasnya 
perjuangan Firdaus dalam menempuh hidupnya.

Sosok Firdaus adalah wanita yang hidup serba berkecukupan yang tidak memiliki pekerjaan tetap demi mempertahakan hidup dia menjalani hidup di dunia hitam. Namun, pengarang menceritakan sosok Firdaus ini tidak selamanya hidup di dunia hitam itu, pengarang menggambarkan sosok Firdaus sabagai tokoh yang tidak mudah menyerah dia terus mencari penghidupan yang normal dengan membaca iklan tentang lowongan kerja. Berkat kegigihannya, akhirnya dia mendapat pekerjaan di sebuah perusahaan. Hal ini dapat dilihat pada kutipan berikut: Data 9:

Setiap kali ada iklan saya ajukan lamaran untuk mendapatkan pekerjaan itu. Saya pergi kesemua kementrian, departemen dan kantor-kantor perusahaan yang mungkin ada lowongan. Dan akhirnya, berkat daya upaya itu, saya memperoleh suatu pekerjaan pada salah satu perusahaan indutri besar (el-Saadawi 2006: 106).

Kutipan di atas menggambarkan bahwa seorang Firdaus berjuang untuk mendapatkan pekerjaan dengan membaca setiap iklan yang terpasang pada mediamedia yang ada. Dari kegigihannya, akhirnya Firdaus mendapatkan pekerjaan pada sebuah perusahaan industri.

\section{Perlawanan Tokoh Utama pada Novel Perempuan di Titik Nol karya Nawal el- Saadawi}

\section{PerlawananTokoh Utama dalam Novel Perempuan di Titik Nol karya Nawal el-Saadawi terhadap Streotip}

Perjuangan para aktivis perempuan sebagian besar memiliki satu kesamaan tujuan yaitu memperjuangkan hak-hak perempuan dan menuntut keadilan gender. Perempuan harus berkiprah di wilayah domestik maupun publik. Saat ini gender yang ditabuh aktivis perempuan dengan konsep peran gandanya sudah mulai mendapat sambutan. Perempuan banyak dijumpai di sektor publik baik di bidang ekonomi, politik dan sosial. Perempuan telah menduduki lembaga legislatif maupun eksekutif. Sungguhpun demikian, apa yang secara esensial diharapkan ternyata belum mendapat hasil maksimal, bahkan tidak dapat disangkal ada pengaruh negatif dari peran ganda perempuan. Salah satu pengaruh negatif itu adalah timbulnya mentalitas dikotomis. Di bawah ini akan diuraikan bentuk perlawana Firdaus dalam novel ini.

Firdaus memcoba menghapus streotip terhadap perempuan atau suatu sikap negatif masyarakat terhadap perempuan yang membuat posisi perempuan selalu pada pihak yang dirugikan. Streotip ini biasa juga menjadi pedoman atau norma yang secara tidak langsung diterapkan oleh berbagai masyarakat.

Data 10:

"pelacur, perempuan jalang. " Kemudian dia menghina ibu saya dengan kata-kata yang tak sanggup saya ikuti. Kemudian, ketika saya berusaha mengucapkannya, saya tak sanggup. Tetapi setelah malam itu , kata-kata itu seringkali saya dengar dari Bayoumi, dan kawankawan Bayoumi (el-Saadawi 2006: 72).

Pada kutipan di atas telah menggambarkan citra perempuan sebagai sosok yang tidak ternilai dimata para kaum laki-laki. Pada kutipan ini juga telah membuktikan bahwa sosok Firdaus adalah perempuan yang berusaha untuk menghapus stigma bahwa perempuan diidentikkan sebagai mahluk rendahan.

Streotip itu sendiri berarti pemberian citra baku atau label/cap kepada seseorang atau kelompok yang didasarkan pada suatu anggapan yang salah atau sesat. Pelabelan umumnya dilakukan dalam dua hubungan atau lebih dan seringkali digunakan sebagai alasan untuk membenarkan suatu tindakan dari satu kelompok atas kelompok lainnya. 


\section{Perlawanan Tokoh Utama dalam Novel Perempuan di Titik Nol karya Nawal el-Saadawit terhadap Marjinalisasi}

Pengarang menggambarkan Firdaus sebagai sosok yang melawan proses marjinalisasi terhadap kaum perempuan, suatu proses peminggiran akibat perbedaan jenis kelamin yang mengakibatkan kemiskinan. Banyak cara yang dapat digunakan untuk memarjinalkan seseorang atau kelompok. Salah satunya adalah dengan menggunakan asumsi gender.

Data 11:

Saya tidak mau kembali kepada kehidupan yang lalu bagaimanapun beratnya siksaan dan penderitaan yang harus saya alami, sekalipun saya tahu lapar dan dingin, serta kemelaratan yang luar biasa. Apapun yang akan terjadi, saya harus menjadi seorang wanita yang terhormat, walaupun harus dibayar dengan nyawa saya (el-Saadawi 2006: 105).

Pada kutipan di atas, pengarang mangambarkan sisi lain dari kehidupan Firdaus yang telah berani untuk tidak ingin selalu berada dalam penguasaan kaum lakilaki dan selalu terpinggirkan. Hal ini membuktikan anggapan bahwa perempuan berfungsi sebagai pencari nafkah tambahan, maka ketika mereka bekerja di luar rumah, seringkali dinilai dengan anggapan tersebut. Jika hal tersebut terjadi, sebenarnya telah berlangsung proses pemiskinan dengan alasan gender.

\section{PerlawananTokoh Utama dalam Novel Perempuan di Titik Nol karya Nawal el-Saadawiterhadap \\ Subordinasi}

Di sisi lain, pengarang menggambarkan diri sosok Firdaus yang berupaya untuk melawan subordinasi terhadap perempuan karena masyarakat menempatkan perempuan pada posisi yang lebih rendah dibanding laki-laki dibangun atas dasar keyakinan satu jenis kelamin dianggap lebih penting atau lebih utama dibanding yang lain. Adanya pendapat bahwa lelaki lebih unggul di bandingkan perempuan, sehingga muncullah asumsi yang menyatakan bahwa kalau ada laki-laki kenapa harus perempuan.

Data 12:

Saya tahu bahwa perempuan tidak bisa menjadi kepala negara, tetapi saya merasa bahwa saya tidak seperti perempuan lainnya, juga anak-anak perempuan lain disekitar saya yang tetap saja berbicara tentang cinta, atau tentang laki-laki (el-Saadawi 2006: 36).

Kutipan ini membuktikan bahwa perempuan tidak bisa mengalahkan dominasi kaum laki-laki. Sosok Firdaus digambarkan oleh pengarang sebagai wanita yang tidak cepat berputus asa atas keadaan yang dia alami, dia berusaha untuk tetap bangkit dari derita yang dialaminya.

Dalam kutipan lain juga dipaparkan tentang dominasi kaun laki-laki.

Data 13:

Saya dapat pula mengetahui bahwa semua yang memerintah adalah lelaki. Persamaan di antara mereka adalah kerakusan dan kepribadian yang penuh distorsi, nafsu, tanpa batas mengumpul uang, seks dan kekuasaan tanpa batas. Mereka adalah lelaki yang menaburkan korupsi di bumi, yang merampas rakyat mereka, yang bermulut besar, berkesanggupan untuk membujuk, memilih kata-kata manis, dan menembakkan panah beracun (el-Saadawi 2006: 39).

4. PerlawananTokoh Utama dalam Novel Perempuan di Titik Nol karya Nawal el-Saadawi terhadap Kekerasan

Hal lain yang digambarkan pengarang sebagai bentuk perlawanan Firdaus adalah kekerasan terhadap 
perempuan. Segala bentuk kekerasan yang akibatnya berupa kerusakan atau penderitaan fisik, seksual, psikologis pada perempuan termasuk ancaman-ancaman dari perbuatan semacam itu, seperti paksaan atau perampasan yang semena-mena atas kemerdekaan, baik yang terjadi di tempat umum atau di dalam kehidupan pribadi seseorang. Dapat dilihat pada kutipan berikut:

Data 14:

Ia mulai mengambil pisau yang ada dalam kantungnya, tetapi tangan saya lebih cepat dari tangannya. Saya angkat pisau itu dan menancapkannya dalam-dalam di lehernya, lalu mencabutnya kembali dan menusukkannya dalam-dalam ke dadanya, mencabutnya keluar dan menusukkannya ke perutnya. Saya tusukkan pisau itu ke hampir semua bagian tubuhnya (elSaadawi 2006: 140).

Pada kutipan di atas menggambarkan sosok Firdaus yang berusaha menghindari kekerasan kepada dirinya sehingga mengakibatkan terbunuhnya sang laki-laki. Hal ini membuktikan bahwa Firdaus anti kekerasan terhadap kaum perempuan. Kekerasan terhadap perempaun sangan tidak asing lagi kita dengarkan akhir-akhir ini.

\section{PENUTUP}

Dari paparan di bagian sebelumnya, dapat disimpulkan bahwa ketidakadilan gender dalam bidang sosial pada novel Perempuan di Titik nol adalah tokoh utama telah banyak mengalami tindakan kekerasan terhadap dirinya, tindakan pelecahan terhadap dirinya serta mendapat penghinaan dan cacian dari kaum laki-laki. Ketidakadilan gender dalam bidang politik pada novel Perempuan di Titik Nol adalah dibatasinya ruang bagi para kaum perempuan untuk terlibat dalam ranah politik. Tokoh Firdaus berharap untuk dapat terlibat dalam dunia politik. Ketidakadilan gender dalam bidang ekonomi pada novel Perempuan di Titik Nol adalah adanya beban kerja yang dialami oleh tokoh Firdaus yang sangat padat sehingga dia harus bekerja keras untuk dapat bertahan hidup. Kedua bentuk perlawan tokoh utama dalam novel Perempuan di Titik nol adalah tokoh utama melawan proses stereotip, marjinalisasi, subordinasi dan kekerasan terhadap perempuan yang digambarkan dalam novel Perempuan di Titik nol.

\section{DAFTAR PUSTAKA}

Agger, Ben. (1998). Teori Sosial Kritis, kritik, penerapan dan implikasinya. Jakarta: Kreasi Wacana.

Alirus, L M. (2008). Aspek Feminisme dalam Novel Serpihan Mutiara Retak Karya Nina Pane. UNM.

Ashaf, A.F. (2009). Jurnalis perempuan dan aktivisme media: Perspektif kritis. Bandung: UNPAD Press.

Ariyana. (2007). Teori Feminisme Radikal (makalah)

http://ariyana.wordpress.com(diakses November 2016).

El-saadawi, N. (2006). Perempuan di Titik Nol. Jakarta. Yayasan Obor Indonesia.

Fakih, Mansour, dkk. 2000. Membincang Feminisme: Diskursus Gender Prespektif Islam. Surabaya: Risalah Gusti.

\section{(2013). Analisis gender}

dan transformasi sosial. Yogyakarta: Pustaka Pelajar.

Gaus, Gerald F. \& Kukathas, Chandran. 2012. Handbook Teori Politik. Bandung: Penerbit Nusa Media.

Gross, E and C. Pateman. 1986. Feminis Challenge: Social and Political Theory. Oston: Northeastern University Press. 
Humm, Maggie. 2007. Ensiklopedia Feminisme. Edisi Bahasa Indonesia diterjemahkan oleh Mundi Rahayu. Yogyakarta: Fajar Pustaka Baru.

Kurnianto, Ery Agus. (2017). Pandangan Empat Tokoh Perempuan Terhadap Virginitas Dalam Novel Garis Perempuan Karya Sanie B. Kuncoro: Perspektif Feminis Radikal. Jurnal Kandai, Vol. 13, No. 2, 281-296.

Milet, Kate. 1970. Sexual Politics. University of Illinois Pres. Urbana and Chicago (https://archive.org/details/KateMill ettSexualPolitics/page/n1).

Nurgiyantoro, Burhan. 2000. Teori Pengkajian Fiksi. Yogyakarta: Pustaka Widyatama.

Rondiyah, Arifa Ainun, dkk. (2017). Aspek Sosial Budaya Masyarakat Makassar
Pada Novel Natisha Karya Khrisna Pabichara. Jurnal Kandai, Vol. 13, No. 2, 223-234.

Sugihastuti \& Suharto. (2002). Kritik Sastra Feminis, Teori dan Aplikasinya. Yogyakarta: Pustaka Pelajar.

Suharto, E. 2002. Teori Feminisme dan Pekerjaan Sosial. (http://www.policy.hu/suharto/Naskah \%20PDF/YogyaFEMINISMESocialW ork.pdf

Suparman. (2014). Pandangan Dunia Pengarang Dalam Novel Larung Karya Ayu Utami (Tinjauan Strukturalisme Genetik Goldmann). Telaga Bahasa. Volume 1. No.2. 